\title{
The Great Wall of Jimbour:1 Heritage and the Cultural Landscape
}

\author{
MICHAEL T. DAVIS
}

Public History Review, vol 12, 2006, pp103-110

V isitors to the homestead complex of Jimbour on the Darling Downs in Queensland are immediately charmed by the stately stone residence that is Jimbour House and the surrounding ancillary buildings of historical significance. Yet, hidden on a grassed and vegetated ridge not far from the northern side of Jimbour House, is a dry stone wall that is a rare, important and little-known aspect of Queensland's cultural heritage. Extending some four miles and originally constructed to a height of about five feet, the wall stands as a memorial to the tenacity and skills of early pastoral workers and was recently listed on the Queensland Heritage Register. ${ }^{2}$ Once dubbed the 'Great Wall of Jimbour', ${ }^{3}$ it sheds light not only on early technologies of land management but also of cultural and spatial adaptation by European settlers. This article takes a closer look at the history of this fascinating remnant of nineteenth-century pastoralism.

\section{BACKGROUND: QUEENSLAND CULTURAL HERITAGE}

While the 'Great Wall of Jimbour' stands as a relic of a bygone era, recognition of its cultural heritage value is indicative of the ascendancy of the heritage industry and popular understandings of history residing in material culture. It is part of a world-wide trend, a cultural mentality that has taken grip over the last forty-five years at least. For one scholar, the 'current craze for heritage seems to me likely to last'. ${ }^{4}$ In Australia, there is a broad sympathy for preserving our past, for protecting cultural heritage places as much for future generations as for an empathy with the past of the present generation. The webpage of the Queensland Environmental Protection Agency summarises the cultural heritage ethos of many Australians: 'Protecting our cultural heritage places is as important as looking after the natural environment. Once they're gone, they can never return. ${ }^{5}$ It is, therefore, not surprising that 'worship of the past' has been referred to as 'one of the great secular religions' in Australia. ${ }^{6}$

Without much conjecture, the opening line in the Preface to $A$ Heritage Handbook states that heritage 'is now big business in Australia. ${ }^{7}$ A whole industry has emerged for the identification, assessment and protection of historic properties and places. ${ }^{8}$ Historians, architects, planners, archaeologists and 
conservationists now band together under the rubric of heritage professionals. Our cultural property is now covered by an extensive legislative framework. ${ }^{9}$ On a national level, the first move towards heritage conservation was made in 1972 when the Whitlam government established a National Estate Grants Programme and a Commission of Inquiry to survey Australian cultural heritage. The Australian Heritage Commission was subsequently established by law in 1975 and at much the same time some of the states enacted their own Heritage Acts. The Historic Buildings Act 1974 in Victoria was the first, followed by the New South Wales Heritage Act 1977 and the South Australian Heritage Act $1978 .{ }^{10}$

Queensland, however - like Western Australia and Tasmania - was slow to enact heritage legislation. Organised efforts to identify and conserve Queensland's heritage were first made by the National Trust, which was established in 1963. As valuable and important as such efforts of the National Trust of Queensland were and still are, it was a community organisation that for the first ten years was managed by volunteers. Its operating budget was small and it lacked statutory authority. Historic buildings were often destroyed during midnight raids, as Queensland development pushed forwards during the 1970s and 1980s with unabated vigour. One local heritage consultant commented: 'The pace, the enthusiasm, and the broadly held belief... that this is the golden age make legislation for the conservation of the cultural heritage... a low priority in the minds of most of the people'. ${ }^{11}$ A free enterprise, laissez faire ethic in Queensland during this period identified progress with development.

This ideology was to be constrained by the enactment of the Queensland Heritage Act 1992. ${ }^{12}$ The Act established the Queensland Heritage Council which advises the Minister for Environment and Heritage on the conservation of cultural heritage, regulates the management of heritage places and maintains the Queensland Heritage Register. While the balance between development and conservation remains at best unstable in Queensland, producing complex legal debates over private property and ownership, ${ }^{13}$ there exists now a general sympathy for and understanding of our historic past. The Queensland Heritage Register, which lists the places, structures and natural formations of heritage significance, provides a record of the value and importance of what was once called our 'cultural resources' and it is fitting that the 'Great Wall of Jimbour' has now taken its place in the Register alongside the other reminders of our past.

\section{JIMBOUR}

The Jimbour run was one of the largest pastoral properties on the Darling Downs, an expansive fertile area discovered by the botanist and explorer Allan Cunningham in $1827 .{ }^{14}$ The Leslie brothers arrived on the Downs in 1840 and took up the first pastoral run of Canning Downs, before Richard Todd Scougall, owner of Liverpool Plains, the following year claimed a run of about $3,000,000$ acres of an area known as Jimba. With the closure of the penal settlement in Brisbane in 1842 the area was opened to free settlement and large pastoral runs on the Darling Downs were selected. When Scougall ran into financial problems 
in 1843, the Jimbour run, stocked with some 11,000 sheep, was sold to Thomas Bell of Parramatta and four years later Bell's sons, John Alexander and Joshua Peter, arrived to manage the property following the death of the original station manager, Henry Dennis. ${ }^{15}$ It was Joshua Bell, however, who eventually took full control of managing Jimbour, raising a family there in the 1860 s and starting his political career at the same time.

In 1863-64, the Bells applied under the right of pre-emptive purchase for the freehold of nine portions of land along Jimbour Creek and around Jimbour head station. A decade of sustained building activity followed, with the construction of a two-storeyed house built of bluestone, a butchery, worker's accommodation and a timber chapel. It was in the 1870 s, however, that the most significant building works began at Jimbour. Joshua Peter Bell became a founding member and director of the Queensland National Bank in 1872 and, flush with money from the wool boom of the 1850s and 1860s, he was well placed to make handsome improvements to the property. In 1873, Brisbane architects Richard Suter and Annesley Voysey were employed to design a new main residence at Jimbour. Suter and Voysey had previously worked on other Darling Downs homesteads ${ }^{16}$ but none rivalled Jimbour for its opulence and grandeur.

Work on Jimbour House commenced in 1874 under the supervision of Harry Ensor, who later served on the Wambo Divisional Board in the early 1880 s. $^{17}$ Constructed from local sandstone, some 200 workmen were employed on the project which lasted three years and cost nearly $£ 30,000 .{ }^{18}$ Until the major improvement work of the 1870s there was little fencing of any consequence on the freehold property and shepherds were employed to control the flocks. ${ }^{19} \mathrm{~A}$ survey plan of Jimbour dated 2 January 1864 shows a number of timber fences on the estate but not a stone wall along the Jimbour ridge.$^{20}$ It was only during the construction of Jimbour House that the stone wall at Jimbour was built, in a period when the station reached its peak as a nineteenth-century pastoral enterprise.

\section{GREAT WALL OF JimBouR}

Dry stone walling is an ancient craft that relies on the skilful placing of stones, not mortar, to produce the strength and durability of the wall. ${ }^{21}$ The craftsmen, also known as cowans, would traditionally lay two parallel rows of stones about three feet apart, with the outer walls gently tapering inwards to the top and the core of the wall filled with rubble. The two sides were bound together by the judicious placing of large capping stones across the top of the wall. This technique, requiring great dexterity and patience, ${ }^{22}$ gained the status of a specialist trade in the eighteenth and nineteenth centuries in Britain, at a time when the enclosure movement gathered momentum. ${ }^{23}$ The south of Scotland, the Lake Districts, the Cotswolds and Wales are particularly rich with dry stone wall heritage, where agriculturalists realised the inherent value of enclosing their fields using this method. Often this was simply as a means of demarcation, a way of distinguishing and marking private property. Dry stone walls helped clear the 
geological landscape of an abundance of surface rocks for the purpose of creating arable land as well as being a cost-effective enclosure for livestock: it is low maintenance, fireproof and highly durable. Moreover, for Britons they not only served a practical purpose but also assumed a certain cultural significance. As Hooker has noted, the 'stone wall of the United Kingdom and Ireland is an ancient and time-honoured way of signifying ownership and control of the countryside. It has an almost religious importance and is a sign of long habitation - of cultivation and the keeping of domesticated livestock. ${ }^{24}$

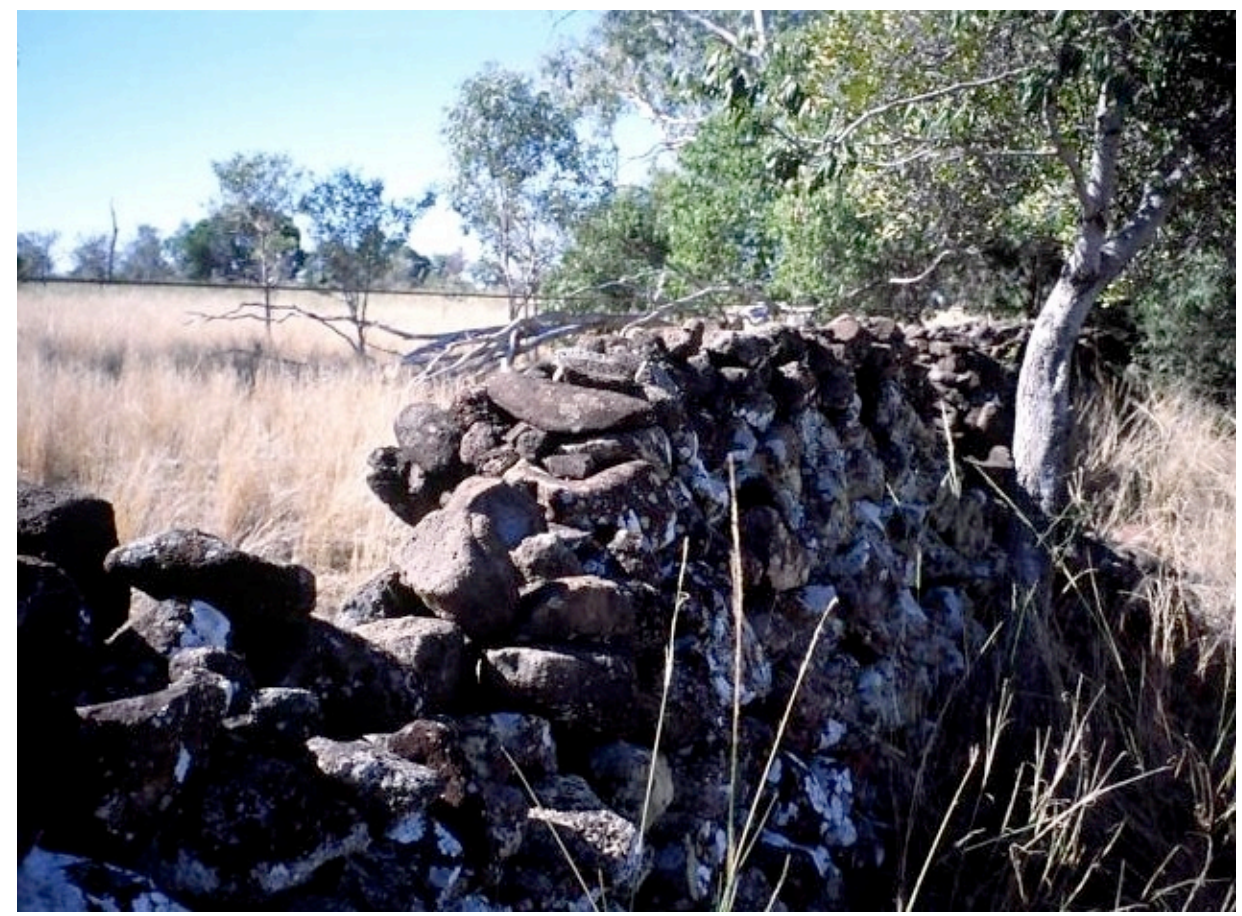

The Jimbour wall (Reproduced courtesy of the Queensland Environmental Protection Agency)

In Australia, dry stone walling appeared in the mid 1800s when Anglo-Celtic and European migrants began plying their trade in the expanding pastoral districts of the country. Serving as a means of clearing the land and spatial management, dry stone walls took on a deeper cultural and nostalgic meaning for early European settlers. In a harsh and unfamiliar environment, stone walls helped transform the landscape into something that resembled their homeland, a process that has been described by one scholar as 'colonisation by mimesis'. ${ }^{25}$ This manipulation of the public sphere and place-making was 'a type of grand clearing that instituted one type of memorialisation over another'. ${ }^{26}$ Much of this activity occurred in Victoria ${ }^{27}$ and the contribution of dry stone walls to the shaping of Australia's cultural and historic landscape has recently been recognised and promoted by the establishment of the Dry Stone Walls Association of Australia in $2002 .^{28}$

In Queensland, there are fewer examples of this historic craft. ${ }^{29}$ One of the most impressive and well-preserved is the dry stone wall at Jimbour. In 1925, 
following extensive restoration of Jimbour House, the Queenslander newspaper printed a story about the property to celebrate the formal re-opening of the house. ${ }^{30}$ The article, written from notes by Harry Ensor, who supervised the building works at Jimbour in the 1870s, records that the first plan was to construct a log fence on the Jimbour ridge. The idea was abandoned due to the abundance of available stone and construction of the stone wall was commenced. It was impressive in its original state, extending about four miles in length, five feet in height, two feet six inches wide at the base and eighteen inches wide at the top. It was rightly dubbed the 'Great Wall of Jimbour', not only on account of its physical extent but also on the grounds that it was the product of enormous human perseverance and ingenuity. The idea of constructing the wall was first conceived by a fellow affectionately known as 'Stonewall Jackson'. ${ }^{31}$ As supervisor of the work gang that built the stone wall, Jackson was responsible for adapting to and overcoming the treacherous conditions of Jimbour ridge. The stony ground meant that the bullocks used to move the stones needed to be continuously shod and the workmen were forced to lace greenhide to their boots for extra protection. The difficult terrain and extent of the wall would have made this a time-consuming task and bears testimony to the endurance and spirit of early European pastoral workers.

Ensor claims that the dry stone wall was built to divide the Jimbour run. The exact meaning of this comment is not known but there is no evidence to suggest that it was used as a line of demarcation. An 1877 survey plan of further Jimbour pre-emptive purchases, drawn by surveyor Martin Lavelle, shows the dry stone wall extending the length of the stony ridge to the north east of the station residence. The wall, however, was not used as a boundary for any of the portions surveyed..$^{32}$ By this time it appears the wall had been in place for several years. The surveyor noted that the wall was in 'a bad state being full of grass' ${ }^{\prime 3}$ and it seems more plausible that it was constructed as a barrier fence. Jimbour in the 1870s was a large sheep station still employing shepherds to manage the flocks. The stony ground, which today remains hazardous to walk across, would have been difficult to patrol on foot and Ensor recollected how, in the early days, 'the grass was on many occasions higher than the sheep and cattle, and one had to watch where the grass was moving in order to locate the sheep. ${ }^{34}$ The wall was constructed to the traditional height required to keep in most breeds of sheep and it seems likely that the main purpose of the wall was to prevent flocks wandering over the grassy ridge. It lessened the burden on the shepherds and served to stop sheep from wandering into an area of Jimbour infested with dingoes. As Ensor explained: 'Dingoes used to give a great deal of trouble, and two men were always kept on to trap these pests, also poison, in order to try and lessen their numbers. ${ }^{35}$

The stone wall may also have served a supplementary purpose of keeping wallabies away from the plains adjacent to the head station where blue grass and wild oats grew. In the late nineteenth century, wallabies were a persistent problem for land owners on the Darling Downs. Many were forced to erect fences 
at great cost in an effort to control the problem. An article in The Brisbane Courier in 1874, reporting on Darling Downs selections around Jandowae, noted the extent of the issue:

I do not exaggerate in stating that as I made my way in, I saw thousands of wallabies retreating quietly before me. These pests would appear to have become perfectly unbearable here, as at the point where the fence runs into the scrub, another fence was in course of construction running along the exterior of the scrub - for the sole purpose of shutting in these little grass devourers... The selections bordering these scrubs are terribly reduced in value by the ravages of the wallabies, and I noticed their paths more than three miles from the scrub. These are strongly marked, wellbeaten paths, used by the vermin to pass out to pastures even more remote, so that evidently their ravages must be felt even five miles from the scrubs which shelter them. ${ }^{36}$

At Jimbour, the stone wall may have been constructed in an effort to control wallaby damage on the plains. And there seems every justification for this. In 1882, the Land Commissioner for the Darling Downs reported to the Lands Department that portions of Jimbour were 'rendered almost useless by reason of being overrun with wallaby'. ${ }^{37}$

In the end, the Jimbour stone wall was not a very effective means of controlling wallabies, if indeed it was meant to at all. It was about two feet lower than it would have needed to be and today sections are in a state of collapse where wallabies have created trails over the wall. With the repurchase of Jimbour in the early twentieth century and subsequent 1909 subdivision of land either side of the Jimbour ridge for closer agricultural settlement, the dry stone wall was used as the approximate demarcation line for subdivisions north and south of the wall. The 1909 surveys cross and re-cross the wall many times, but the survey lines mostly follow within a few metres of the stone wall. ${ }^{38}$

\section{CONCLUSION}

Today, the 'Great Wall of Jimbour' symbolises the rise of the cultural heritage industry in Australia and more particularly in Queensland. Its identification and recognition as a site of heritage significance is indicative of the growing popular appreciation of our historic past. Importantly the wall stands as a lasting reminder of yesteryear. To wander along the length of this wall is a throwback in time. Sections of the wall remain in a relatively well-preserved state, unmoved for over 130 years. The preservation and overall structural integrity of the wall is testimony to the skills of early pastoral workers in the regional areas of Queensland. It is an added reminder of the cultural heritage significance of Jimbour. Alongside the heritage-listed mansion and ancillary buildings is this rare and important example 
of traditional European technology used by early settlers in controlling, shaping and adapting to their new colonial environment. It is their lasting mark on the landscape, a sign of their time there and an indication of their physical and cultural assimilation. The Jimbour dry stone wall is truly one of the most intriguing heritage landmarks, a memorial of nineteenth-century Australian history.

\section{ENDNOTES}

\footnotetext{
${ }^{1}$ I wish to acknowledge that the research on which this paper is based was carried out as a heritage assessment for the Queensland Environmental Protection Agency and that the Agency is the copyright owner of the written history, description and assessment of significance as included in the Queensland Heritage Register. I am grateful to the Environmental Protection Agency for granting permission to use the research and assessment as part of this article. I would also like to thank David Russell and the staff at Jimbour House who helped facilitate a research visit to the property.

${ }^{2}$ Queensland Heritage Register Place ID 602415.

3 'The Story of Jimbour House', in The Queenslander, 12 December 1925, p11.

${ }^{4}$ David Lowenthal, The Heritage Crusade and the Spoils of History, Viking, London, 1996, p2.

${ }^{5}$ Cited from the following webpage of the Queensland Environmental Protection Agency: http://www.epa.qld.gov.au/cultural heritage/protecting cultural heritage/protecting cultural heritage/

${ }^{6}$ Cited in Lowenthal, op cit, p1.

${ }^{7}$ Graeme Davison and Chris McConville (eds), A Heritage Handbook, Allen \& Unwin, North Sydney, 1991, pvii.

${ }^{8}$ See Graeme Davison, 'A Brief History of the Australian Heritage Movement', in Davison and McConville, pp14-29.

${ }^{9}$ See Maurice Evans, Principles of Environmental and Heritage Law, Prospect Media, St Leonards, 2000; Ben Boer and Graeme Wiffen, Heritage Law in Australia, OUP, Melbourne, 2006.

${ }^{10}$ For a discussion of state heritage legislation see Sheryl Yelland, 'Heritage Legislation in Perspective', in Davison and McConville, op cit, pp43-61.

${ }^{11}$ Cited in Davison, 'A Brief History of the Australian Heritage Movement', in Davison and McConville, p.25.

${ }^{12}$ For an overview of the Act see A. Innes, 'Application of the Queensland Heritage Act 1992', Australian Environmental Law News, no 2, 1993, pp7-10.

${ }^{13}$ See C. Arnold, 'Valuing Our Built Heritage: Who Pays for its Preservation?', Queensland Law Society Journal, vol 23, no 5, 1993, pp451-68; P.L. Pan, 'Ownership and Control: An Analysis of the Queensland Heritage Act 1992', Queensland Law Society Journal, vol 23, no 3, 1993, pp223-42.

${ }^{14}$ For the early history of the Darling Downs district, see Maurice French, $A$ History of the Darling Downs Frontier, Darling Downs Institute Press, Toowoomba, 1989; and Maurice French, Explorations in Frontier History: Darling Downs, 1840-1860, University of Southern Queensland Press, Darling Heights, 1997.

${ }^{15}$ For the early history of Jimbour, see C.W. Russell, Jimbour: Its History and Development, 1840-1953, Watson \& Ferguson, Brisbane, 1955. For the history of Jimbour to 1982, see Hilary Maude Russell, Jimbour: Its History and Development, 1955-1982, The Dalby Herald, Dalby, 1982.

${ }^{16}$ Suter designed Talgai Homestead near Allora in 1868. See Queensland Heritage Register Place ID 600006. Suter and Voysey also designed Westbrook Hall near Drayton in 1873-76.

${ }^{17}$ Queensland Post Office Directory, Hollander Wright, Brisbane, 1883-84.

${ }^{18}$ See a typescript 'History of Jimbour House and its Occupants', 1973, by Sybil Bell, in University of Queensland Fryer Library, UQFL.68, C.W. Russell Papers, Box 19.

${ }^{19}$ G.H. Routley, 'Old Jimbour and the Darling Downs', The Bulletin, 31 December 1952, p23.

${ }^{20}$ Queensland Department of Natural Resources, Mines and Energy, Survey Plan D35119 (1864).

${ }^{21}$ See Lawrence Garner, Dry Stone Walls, Shire Publications, Buckinghamshire, 2005.

${ }^{22}$ The construction of a dry stone wall was labour intensive and progressed at a slow rate. It is estimated that a solo waller could build approximately five metres per day: ibid, p4.

${ }^{23}$ See J.M. Neeson, Commoners: Common Right, Enclosure and Social Change in England, 1700-1820, Cambridge University Press, Cambridge, 1993; J.A. Yelling, Common Field and Enclosure in England, 1450-1850, Macmillan, London, 1977.

${ }^{24}$ John Hooker, If These Walls Could Talk: A Report for the Corangamite Dry Stone Walls Project, Corangamite Arts Council, Corangamite, 1995.

${ }^{25}$ Paul Carter, The Lie of the Land, Faber and Faber, London, 1996, p6.
} 
${ }^{26}$ ibid

${ }^{27}$ Rod McLellan, 'The Dry Stone Walls of Victoria's Western District', Historic Environment, no 7, 1989, pp28-32.

${ }^{28}$ Information about the Dry Stone Walls Association of Australia can be seen at http://www.astoneuponastone.com/index.html.

${ }^{29}$ There are only several listings of dry stone walls on the Queensland Heritage Register: Sunnyside Sugar Plantation Wall (Place ID 601700); South Sea Islander Wall (Place ID 602230); Melton Hill, Townsville, Dry Stone Wall (Place ID 600885).

30 'The Story of Jimbour House' in The Queenslander, 12 December 1925, p11.

${ }^{31}$ The name 'Stonewall Jackson' was first used in reference to Thomas Jackson, a general in the Confederate army during the American Civil War. The epithet took its rise from the battle of Bull Run in July 1861, when General Bernard Bee reputedly told his troops: 'See, there is Jackson, standing like a stone wall'. It was in reference to Jackson's steadfastness in the face of the enemy. See James I. Robertson, Stonewall Jackson: The Man, the Soldier, the Legend, Macmillan, New York, 1997; Byron Farwell, Stonewall: A Biography of Thomas J. Jackson, W.W. Norton, New York, 1992.

${ }^{32}$ Queensland Department of Natural Resources, Mines and Energy, Survey Plan A34.41005 (1877).

${ }^{33}$ ibid.

34 'The Story of Jimbour House' in The Queenslander, 12 December 1925, p11.

${ }^{35}$ ibid.

${ }^{36}$ The Brisbane Courier, 23 May 1874, p5.

${ }^{37}$ Land Commissioner for the Darling Downs to the Lands Department, 29 December 1882, Queensland State Archives, LAN/AF208, Jimbour Run file.

${ }^{38}$ Queensland Department of Natural Resources, Mines and Energy, Survey Plan AG.589 (1908); Survey Plan AG.679 (1909); Survey Plan AG.680 (1909). 